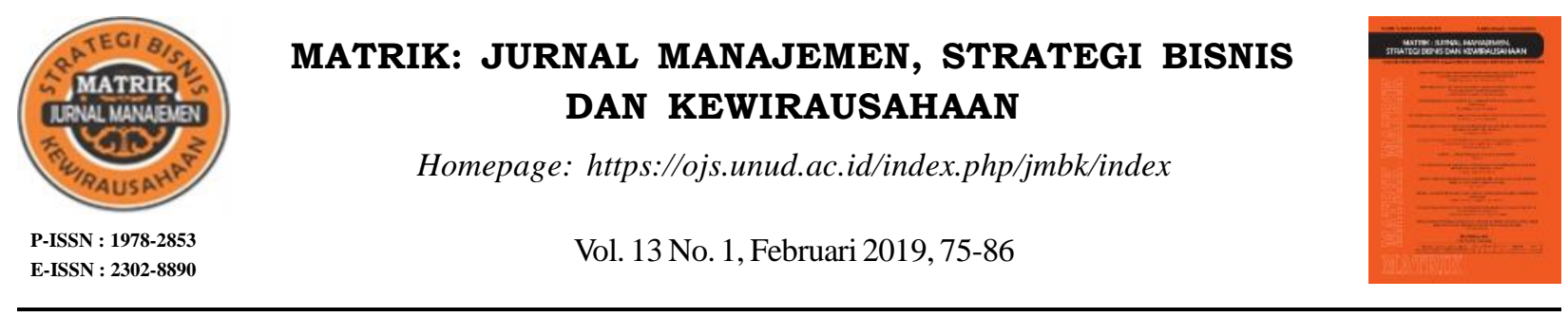

\title{
UJI INTEGRASI PASAR MODAL DAN CONTAGION EFFECT SEBELUM DAN SESUDAH BREXIT PADA PASAR MODAL ASEAN
}

\author{
Prayogo $^{1)}$, Harijono ${ }^{2)}$, Robiyanto ${ }^{3)}$ \\ ${ }^{1,2,3)}$ Fakultas Ekonomika dan Bisnis Universitas Kristen Satya Wacana \\ email: robiyanto.robiyanto@uksw.edu
}

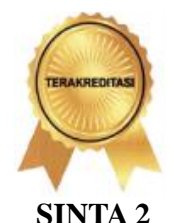

DOI : https://doi.org/10.24843/MATRIK:JMBK.2019.v13.i01.p08

\begin{abstract}
ABSTRAK
Penelitian ini mengkaji integrasi pasar modal dan efek penularan antara pasar modal di kawasan ASEAN dengan pasar modal Inggris, sebelum dan sesudah acara Brexit. Analisis data akan dibagi sebelum Brexit (Januari 2012 - 22 Juni 2016) dan setelah Brexit (24 Juni 2016 - Desember 2016). Alat analisis yang digunakan adalah Vector Autoregressive (VAR) untuk menganalisis integrasi antara pasar modal dan Granger Causality untuk mendeteksi efek penularan antara pasar modal. Kesimpulan dari penelitian ini adalah bahwa adanya peristiwa Brexit dapat mengubah kawasan ASEAN-5 yang tersegmentasi menjadi lebih terintegrasi. Ditemukan pula bahwa pasar modal Singapura adalah pasar modal yang menerima efek penularan dari pasar modal Inggris sebelum dan sesudah Brexit. Adapun pasar modal Indonesia, Malaysia, Filipina, dan Thailand hanya menerima efek penularan antar wilayah, kecuali pasar modal Filipina setelah Brexit tidak menerima efek penularan dari semua negara.

Kata kunci: integrasi pasar modal, efek penularan, vector autoregressive (VAR), granger causality test, brexit.

CAPITAL MARKET INTEGRATION TEST AND CONTAGION EFFECT BEFORE AND AFTER BREXIT IN ASEAN CAPITAL MARKET
\end{abstract}

\begin{abstract} did not receive contagion effects from any country. brexit

\section{PENDAHULUAN}

Kerjasama antar negara kawasan ASEAN mengalami perkembangan yang cukup pesat mulai dari kerjasama politik, ekonomi dan keamanan. Perkembangan ekonomi terbentuk dari adanya Preferential Trade Arrangement (PTA), Free Trade Area (FTA), kemudian menjadi ASEAN Economic Community (AEC). AEC ini merupakan realisasi dari aspirasi ASEAN sebagai kawasan yang stabil, makmur, mempunyai daya kompetitif yang tinggi sehingga berfungsi sebagai pasar tunggal dan
\end{abstract}

This study examined the capital market integration and contagion effect among the ASEAN and UK capital markets, before and after the Brxit. The data analysis is divided into before the Brexit (Januari 2012 - 22 Juni 2016) and after the Brexit (24 Juni 2016 - Desember 2016). The analysis tools used are the Vector Autoregressive (VAR) to analyze the integration between capital markets and the Granger Causality to detect the contagion effect between capital markets. The conclusion of this study is that the Brexit was able to cause the segmented ASEAN-5 regions to be more integrated. It was also found that the Singaporean capital market is the capital market which received the greatest contagion effect from UK's capital market before and after the Brexit. The capital market of Indonesia, Malaysia, Philippine, and Thailand only received contagion effects between regions, while the capital market of Philippine

Keywords: capital market integration, contagion effect, vector autoregressive (VAR), granger causality test,

wilayah basis produksi pada tahun 2020 mendatang, dengan program kebebasan aliran barang, tenaga kerja, aliran modal, namun juga untuk mengurangi kemiskinan dan kesenjangan sosial ekonomi (Soesastro, 2004). Lebih lanjut, cetak biru AEC direncanakan adanya liberalisasi jasa-jasa keuangan diantara negara anggota ASEAN dengan tujuan untuk mempercepat perkembangan dan integrasi pasar modal, serta tidak kalah pentingnya adalah adanya rencana pengurangan bahkan penghilangan batasan lalu lintas permodalan untuk mencapai arus 
modal yang lebih bebas di kawasan antar negara anggota ASEAN (Muharam, 1999; Volz, 2013).

Semakin terintegrasinya pasar-pasar modal ditandai oleh makin tingginya korelasi antara return saham antar bursa saham, dimana korelasi yang semakin tinggi disebabkan oleh beberapa hal yaitu bias yang makin menurun dalam pilihan portofolio, makin beranekaragamnya penjualan dan pendanaan perusahaan-perusahaan, fenomena sementara atau konvergensi industry dan koordinasi kebijakan antar negara yang makin tinggi intensitasnya (Arsyad, 2015; Robiyanto, 2017a; Robiyanto dan Hartanto, 2018). Valle (1999) menyebutkan bahwa pasar modal suatu negara dapat mengalami pergerakan yang sama (comovement) karena adanya faktorfaktor ekonomi yang mendasarinya (underlying factors), yang mencerminkan kondisi keuangan di dunia secara umum, dan secara sistematis mempengaruhi semua pasar, sebagai contohnya yaitu adanya deregulasi dan liberalisasi pasar, perkembangan teknologi komunikasi dan sistem perdagangan, inovasi pada produk dan jasa keuangan serta makin meningkatnya aktivitas internasional dari perusahaan-perusahaan multinasional juga mempengaruhi comovement pasar modal di berbagai negara (Papavassiliou, 2014; Robiyanto dan Ernayani, 2018).

Integrasi finansial menjadi hal yang tidak dapat dipisahkan dari adanya kerjasama antar negara anggota ASEAN, sehingga dengan terintegrasinya pasar modal ASEAN akan meningkatkan peran pasar modal dalam pembangunan ekonomi negaranegara kawasan ASEAN (Robiyanto, Hersugondo, dan Chotijah, 2016). Seperti yang dikemukakan oleh Liaw (2004) pentingnya peran pasar modal merupakan sumber pendanaan jangka panjang bagi korporasi dan untuk memperoleh keuntungan bagi investor sehingga terintegrasinya bursa-bursa saham akan memberikan peluang bagi perusahaanperusahaan untuk memperoleh dana atau modal lebih efisien dan bagi investor dapat menanamkan modalnya pada sekuritas dalam bentuk portofolio investasi. Keberhasilan dari kerjasama ASEAN ditentukan oleh stabilnya perekonomian antar negara anggota yang kedepannya bisa memberikan manfaat bagi negara yang berada di kawasan tersebut dan berkontribusi bagi perkembangan finansial pada wilayah negara anggota di kawasan ASEAN dengan ekonomi yang masih jauh dari perekonomian yang lebih maju, sebagai contohnya dapat bekerjasama membantu investor di kawasan ASEAN dalam memprediksikan pergerakan asset-aset di kawasan ASEAN di masa mendatang (Robiyanto, 2017a, 2018b; Robiyanto dan Ernayani, 2018; Suryanta, 2011).

Kestabilan perekonomian suatu negara tidak bisa terlepas dari adanya peristiwa yang terjadi baik secara domestik maupun eksternal (Mensi, Beljid, Boubaker, dan Managi, 2013; Robiyanto, 2018a; Robiyanto, Wahyudi, dan Pangestuti, 2017b). Peristiwa eksternal yang bergejolak di negara besar, dapat mempengaruhi kondisi perekonomian negara yang pada akhirnya akan berdampak terhadap pergerakan harga saham maupun integrasi pasar modal suatu negara (Suganda dan Soetrisno, 2016). Kategori peristiwa yang mengejutkan di dunia investasi pada tahun 2016 adalah adanya referendum keluarnya negara Inggris dari Uni Eropa yang dikategorikan dalam resiko sistematik yang dapat mempengaruhi ekonomi di kawasan, memang tidak dapat dipungkiri integrasi finansial tidak lepas dari adanya resiko, dimana peristiwa di negara lain dapat memberikan efek penularan atau sering disebut dengan contagion effect ke negara lain dan hal ini tidak menutup kemungkinan dapat berimbas ke negara-negara di kawasan ASEAN (Seth dan Sharma, 2015).

Sementara itu ada beberapa penelitian terdahulu yang menunjukan bahwa pasar modal di negara maju memiliki pengaruh terhadap pasar modal di beberapa kawasan ASEAN diantaranya, Ibrahim (2006) melakukan kajian pasar modal dengan menggunakan simple regression dan Vector Autoregressive (VAR) dengan periode penelitian dari Januari 1988 sampai dengan Desember 2003, penelitian ini meneliti pengaruh pasar modal yang sudah maju seperti pasar modal Amerika dan Jepang terhadap pasar modal kawasan ASEAN. Hasil penelitiannya menunjukkan bahwa pasar modal Amerika lebih dominan dari pada pasar modal Jepang dalam mempengaruhi pasar modal ASEAN, bukti yang kuat dengan menunjukkan adanya respon pasar modal ASEAN terhadap kemerosotan pasar modal Amerika meskipun perubahan positif tidak begitu berpengaruh signifikan ke pasar modal ASEAN tetapi pasar modal ASEAN lebih rentan terhadap kemerosotan pasar modal global khususnya dari Amerika (Mulyadi, 2012).

Suryanta (2011) melakukan penelitian tentang integrasi pasar modal di beberapa negara anggota ASEAN periode Januari 2004 hingga Desember 2009 yang dianalisis dengan VAR. hasil penelitiannya yakni tidak terdapat comovement dan 
keterkaitan pasar modal Indonesia dengan pasar modal Malaysia, Singapura, Thailand dan Filipina. Lebih lanjut Suryanta (2011) mengemukakan bahwa faktor domestik Indonesia lebih mempengaruhi pasar modal Indonesia dibandingkan dengan faktor eksternal. Secara terpisah, Karim and Karim (2012) meneliti mengenai integrasi pasar modal di beberapa negara kawasan ASEAN seperti Indonesia, Malaysia, Singapura, Thailand dan Filipina dengan periode penelitian Januari 1988 sampai dengan Desember 2010 yang terbagi dalam dua periode sebelum 1997 dan setelah 1997 serta setelah terjadi krisis finansial di Amerika Serikat. Hasil kesimpulan penelitiannya menerangkan bahwa pasar modal di negara-negara anggota ASEAN makin terintegrasi terutama setelah terjadinya krisis finansial di Amerika Serikat. Daly (2012) menemukan adanya hubungan jangka panjang antara indeks pasar modal negara Indonesia, Malaysia, Thailand, Singapura,Filipina, dan juga Vietnam, yang menggunakan data penelitian selama 5 tahun dari 2006 -2010 guna melihat perubahan yang terjadi pada indeks pasar negara tersebut saat terjadi Global Financial Crisis (GFC) dan hasilnya menunjukkan bahwa krisis yang terjadi di Amerika Serikat sekitar pertengahan tahun 2007 baru terdampak signifikan ke pasar Asia Tenggara pada pertengahan awal tahun 2008. Kajian yang lebih baru dilakukan oleh Suganda and Soetrisno (2016) yang menemukan bukti empiris bahwa pasca krisis Amerika tahun 2008 dan krisis Yunani tahun 2010 terdapat integrasi dan keterkaitan pasar modal Indonesia, Malaysia, Filipina, Thailand, Singapura. Lebih lanjut ditemukan pula efek penularan (contagion effect) di beberapa negara kawasan ASEAN pasca terjadinya Suprime Mortgage tahun 2008 dan krisis Yunani pada tahun 2010.

Penelitian-penelitian yang telah dijabarkan sebelumnya tersebut, kebanyakan masih menggunakan periode yang melibatkan Asian Crisis tahun 1998 dan Global Financial Crisis tahun 2008 sebagai batasan periodenya. Masih jarang penelitian yang melakukan kajian dengan menggunakan peristiwa Brexit sebagai periode pembatasnya. Pada peristiwa Brexit ini merupakan peristiwa yang penting yang berdampak besar bagi pasar finansial di dunia. Peristiwa Brexit berpotensi mengubah derajat integrasi pasar modal di dunia karena ketika peristiwa Brexit terjadi penurunan harga saham yang cukup dalam di berbagai pasar modal di dunia.
Mempertimbangkan adanya potensi resiko akibat dari integrasi pasar modal yang berupa efek penularan (contagion effect), maka penelitian ini dilakukan untuk memberikan bukti adanya integrasi pasar modal dan contagion effect sebelum dan sesudah peristiwa Brexit pada Indeks Harga Saham Gabungan (IHSG) untuk Indonesia, Kuala Lumpur Composite Index (KLCi) untuk Malaysia, PSE Composite Index (PSEi) untuk Philipina, SET Index (SETi) untuk Thailand, Straight Times Index (STI) untuk Singapura, serta FTSE Index untuk Inggris. Pemilihan obyek penelitian ini adalah pada pasar modal kawasan ASEAN-5 dikarenakan Indonesia, Malaysia, Philipina, Thailand dan Singapura merupakan cikal bakal atau pelopor berdirinya ASEAN serta kelima negara ini memiliki perkembangan pasar modal yang cukup pesat dibandingkan negara ASEAN lainnya (Robiyanto, Wahyudi, dan Pangestuti, 2017a), kemudian FTSE Index untuk negara Inggris dikarenakan Inggris merupakan salah satu negara maju dikawasan Eropa yang dapat mempengaruhi pasar modal kawasan, serta obyek peristiwa dalam penelitian ini adalah Brexit yang diperkirakan dapat mempengaruhi perekonomian global dan kawasan atau wilayah tertentu.

Tahun 2016 menjadi tahun kejutan dan ketidakpastian bagi perekonomian global, hal ini terjadi karena adanya beberapa peristiwa diantaranya: kekhawatiran perlambatan ekonomi Tiongkok yang menyebabkan jatuhnya pasar saham dunia pada awal tahun 2016, kemudian 23 Juni 2016 Inggris keluar dari keanggotaan Uni Eropa (Brexit), ditambah dengan terpilihnya Donald Trump sebagai Presiden Amerika Serikat pada 8 November 2016 (DBS, 2017). Inggris bergabung dalam Uni Eropa sejak tahun 1973, selama 27 tahun terakhir Inggris telah mengalami defisit perdagangan antar anggota Uni Eropa dengan kisaran defisit sebesar 30 juta poundsterling per hari, sebaliknya neraca perdagangan Inggris mengalami surplus disetiap benua di dunia, sedangkan pada tahun 2010 kontribusi kotor Inggris untuk anggaran Uni Eropa mencapai 14 miliar poundsterling, dimana Inggris hanya bisa menyimpan 7 miliar poundsterling setahun dengan seluruh pengeluaran pemerintah (FKMHII, 2016). Permasalahan yang dihadapi masyarakat Inggris dalam Uni Eropa adalah intervensi yang terlalu jauh terhadap kedaulatan suatu negara, dimana Inggris ingin menjaga kedaulatannya 
sendiri. Lebih lanjut FKMHII (2016) menjelaskan bahwa suatu negara akan lebih baik dan menguntungkan apabila dapat memerintah, membuat, melaksanakan, menerapkan hukum dan tarif pajaknya sendiri karena sejak tahun 2010 Uni Eropa telah memperkenalkan 3.500 hukum baru yang mempengaruhi bisnis Inggris, pengaruh bisnis tersebut mendatangkan kerugian bagi pihak Inggris dan mengakibatkan rasa kekecewaan masyarakat Inggris

Setelah adanya beberapa regulasi yang memberatkan dan merugikan Inggris, kemudian munculah niat Inggris keluar dari keanggotaan Uni Eropa yang kemudian disebut dengan peristiwa Brexit (Britania Raya Exit) merupakan keputusan referendum keluarnya Inggris dari Uni Eropa sehingga menjadi sebuah fenomena pada bulan Juni 2016. Referendum tersebut memberikan dampak terhadap perekonomian global. Pasar keuangan global langsung mengalami guncangan sesaat setelah adanya referendum dimana para investor melakukan aksi jual dan beli kemudian mengalihkan investasinya ke instrumen keuangan yang dianggap sebagai safe haven seperti obligasi pemerintah, hal ini membuat bursa Inggris mengalami koreksi yang sangat tajam serta kondisi saat ini juga membuat mata uang Inggris mengalami pelemahan yang cukup tajam terhadap US dollar.

Dampak Brexit bagi Indonesia dan anggota ASEAN lainnya menurut Nainggolan (2016) menyebutkan bahwa Inggris adalah salah satu negara yang berpengaruh dalam Uni Eropa, sehingga akan merepotkan distribusi dan penjualan, serta menggangu permintaan pasar komoditi Indonesia, dengan adanya Brexit Indonesia harus bernegosiasi dengan Inggris yang terpisah dari Uni Eropa, sehingga akan merugikan potensi akses pasar Indonesia dan para investor harus mewaspadai jika hasil referendum tidak diharapkan pasar. Oleh karena itu persoalan penelitian ini adalah: apakah dengan adanya peristiwa Brexit dapat mengubah kawasan ASEAN-5 yang tersegmentasi menjadi lebih terintegrasi? Sehingga tujuan dari penelitian ini adalah untuk menunjukan bukti adanya integrasi pasar modal dan contagion effect sebelum dan sesudah peristiwa Brexit pada IHSG, KLCi, PSEi, SETi, STI, dan FTSE. Adapun manfaat penelitian ini secara teoritis diharapkan bisa memberikan kontribusi dibidang akademis sebagai referensi penelitian selanjutnya, manfaat praktis bagi investor agar lebih memperhatikan peristiwa global sebagai pertimbangan pengambilan keputusan investasi, serta manfaat untuk peneliti supaya dapat menganalisis tentang integrasi dan contagion effect di beberapa pasar modal antara IHSG, KLCi, PSEi, SETi, STI dan FTSE sebelum dan sesudah peristiwa Brexit.

\section{METODE PENELITIAN}

Populasi dalam penelitian ini menggunakan indeks harga saham gabungan dari pasar modal antar negara meliputi Indonesia, Malaysia, Filipina, Singapura, Thailand dan Inggris. Sampel dari penelitian ini adalah harga penutupan harian dari masing-masing indeks harga saham gabungan yaitu Indeks Harga Saham Gabungan (IHSG) untuk Indonesia, Kuala Lumpur Composite Index (KLCi) untuk Malaysia, PSE Composite Index (PSEi) untuk Philipina, Straight Times Index (STI) untuk Singapura, SET Index (SETi) untuk Thailand, dan FTSE Index untuk Inggris.

Penelitian ini menggunakan data kuantitatif yang berasal dari data sekunder yang merupakan data times series harian selama 5 tahun dari bulan Januari 2012 sampai dengan Desember 2016 yang dibagi ke dalam 2 periode, yaitu sebelum dan sesudah terjadi peristiwa Brexit. Periode pertama yaitu sebelum terjadi peristiwa Brexit dimulai dari bulan Januari 2012 sampai tanggal 22 Juni 2016. Periode kedua yaitu sesudah peristiwa Brexit dari tangggal 24 Juni 2016 sampai dengan tanggal 31 Desember 2016. Pengambilan data diperoleh dari Bloomberg.

Unit Root Test atau uji akar unit adalah uji yang digunakan untuk stasioneritas data time series (Robiyanto, 2017b). Metode uji stasioneritas dilakukan dengan uji akar-akar unit root test yang dilakukan dengan menggunakan Uji Augmented Dickey Fuller (ADF) (Robiyanto, 2018a). Setelah data terbukti bersifat stasioner, maka dilakukan uji kausalitas Granger dan Vector Autoregression (VAR). Uji kausalitas granger ini dilakukan untuk mengetahui apakah suatu variabel endogen dapat diperlakukan sebagai variabel eksogen. Untuk menentukan signifikansi arah hubungan kausalitas antar variabel menggunakan nilai probabilitas ( $p$ value) yang dihasilkan. Jika probabilitas lebih kecil dari $\alpha=5 \%$ atau 0,05 maka dapat dikatakan terjadi kausalitas yang signifikan.

Metode VAR merupakan sebuah metode untuk menganalisis sebuah hubungan antar variabel yang tidak didasarkan pada teori tertentu (Widarjono, 2016). Berbeda dengan model persamaan simultan, dalam VAR tidak perlu dilakukan pembedaan antara 
variabel endogen dan eksogen karena dalam pendekatan VAR semua variabel yang dipercaya saling berhubungan dimasukkan ke dalam model. Analisis VAR dilakukan dengan menggunakan aplikasi program EVIEWS 7.

\section{HASIL DAN PEMBAHASAN}

Uji Unit Root Test atau uji kestasioneran data dilakukan dengan menggunakan Augmented Dickey Fuller (ADF) untuk melihat tingkat stasioner data pada level, 1st difference, 2nd difference.

Tabel 1. Augmented Dickey Fuller Test Statistic periode Januari 2012 - 22 Juni 2016

\begin{tabular}{|c|c|c|c|c|c|c|c|}
\hline \multicolumn{2}{|c|}{ Test for unit root in } & FTSE & IHSG & KLCi & PSEi & SETi & STI \\
\hline \multirow{2}{*}{ Level } & t-stat. & $-2,5432$ & $-2,4141$ & $-2,0228$ & $-2,8358$ & $-2,3795$ & $-2,0516$ \\
\hline & Prob. & 0,3070 & 0,3719 & 0,5876 & 0,1846 & 0,3901 & 0,5717 \\
\hline \multirow{2}{*}{$\begin{array}{l}\text { 1st } \\
\text { difference }\end{array}$} & t-stat. & $-34,16^{* * *}$ & $-30,95^{* * *}$ & $-30,39 * * *$ & $-30,08 * * *$ & $-31,99 * * *$ & $-32,30 * * *$ \\
\hline & Prob. & 0,0000 & 0,0000 & 0,0000 & 0,0000 & 0,0000 & 0,0000 \\
\hline
\end{tabular}

Sumber: Data diolah, 2017

Keterangan :

*signifikan pada tingkat $10 \%$

**signifikan pada tingkat 5\%

$* * *$ signifikan pada tingkat $1 \%$

Hasil uji kestasioneran data sebelum Brexit periode Januari 2012 - 22 Juni 2016 dapat dilihat pada Tabel 1. Hasil uji ADF pada Tabel 1. menunjukkan pada tingkat level semua data (FTSE, IHSG, KLCi, PSEi, SETi, STI) masih terdapat unit root atau data belum stasioner, sehingga perlu dilanjutkan ke tingkat uji 1st difference, hasil yang ditunjukan pada Tabel 1. dapat disimpulkan semua data telah stasioner pada tingkat 1st difference dengan tingkat signifikansi pada 1 persen.

Tabel 2. Augmented Dickey Fuller Test Statistic periode 24 Juni 2016- 31 Desember 2016

\begin{tabular}{cccccccc}
\hline \multicolumn{2}{c}{ Test for unit root in } & FTSE & IHSG & KLCi & PSEi & SETi & STI \\
\hline \multirow{2}{*}{ Level } & t-stat. & $-3,6053^{* *}$ & $-3,3594^{*}$ & -2.9343 & $-3.4273^{*}$ & -2.8693 & -2.9361 \\
& Prob. & 0,0331 & 0,0617 & 0,1554 & 0.0523 & 0.1761 & 0.1548 \\
1st & t-stat. & - & - & $-11.2328^{* * *}$ & - & $-9.7768^{* * *}$ & $-9.9641^{* * *}$ \\
difference & Prob. & - & - & 0,0000 & - & 0,0000 & 0,0000 \\
\hline
\end{tabular}

Sumber: Data diolah, 2017

Keterangan :

*signifikan pada tingkat $10 \%$

**signifikan pada tingkat $5 \%$

$* * *$ signifikan pada tingkat $1 \%$

Hasil uji kestasioneran data sesudah Brexit periode 24 Juni 2016- 31 Desember 2016 pada Tabel 2. Untuk hasil uji ADF yang tersaji pada Tabel 2. menunjukan bahwa FTSE, IHSG, dan PSEi sudah stasioner pada tingkat level dengan tingkat signifikansi pada 5 persen dan 10 persen, sedangkan $\mathrm{KLCi}$, SETi, dan STI masih terdapat unit root pada tingkat level sehingga harus dilakukan uji $1 s t$ difference, pada tingkat ini semua data sudah bersifat stasioner dengan tingkat signifikansi pada 1 persen.
Syarat untuk melakukan uji VAR adalah data yang berupa time series harus bersifat stasioner dan sebelum melakukan uji VAR harus menentukan lag optimum menggunakan lag length criteria dengan melihat nilai AIC yang paling rendah. Tabel 3 . (sebelum Brexit periode Januari 2012 - 22 Juni 2016) menunjukan hasil lag optimum pada uji lag length criteria dengan nilai AIC yang paling rendah ditunjukan pada lag ke-5 dengan nilai AIC sebesar 57,06832 . 
Tabel 3. Hasil Uji Lag Length Criteria periode Januari 2012 - 22 Juni 2016

\begin{tabular}{ccccccc}
\hline Lag & LogL & LR & FPE & AIC & SC & HQ \\
\hline 0 & -30826.28 & NA & $2.81 \mathrm{e}+17$ & 57.20274 & $57.23047 *$ & $57.21324^{*}$ \\
1 & -30758.90 & 133.8801 & $2.65 \mathrm{e}+17$ & 57.14452 & 57.33866 & 57.21804 \\
2 & -30710.04 & 96.54067 & $2.58 \mathrm{e}+17$ & 57.12066 & 57.48121 & 57.25720 \\
3 & -30665.77 & 86.97751 & $2.55 \mathrm{e}+17$ & 57.10532 & 57.63227 & 57.30487 \\
4 & -30614.88 & 99.41436 & $2.48 \mathrm{e}+17$ & 57.07770 & 57.77105 & 57.34026 \\
5 & -30573.82 & 79.75742 & $2.45 \mathrm{e}+17 *$ & $57.06832 *$ & 57.92807 & 57.39389 \\
6 & -30540.56 & 64.24526 & $2.47 \mathrm{e}+17$ & 57.07339 & 58.09955 & 57.46198 \\
7 & -30507.79 & 62.91634 & $2.48 \mathrm{e}+17$ & 57.07939 & 58.27195 & 57.53099 \\
8 & -30475.19 & $62.23463^{*}$ & $2.50 \mathrm{e}+17$ & 57.08570 & 58.44467 & 57.60032 \\
\hline
\end{tabular}

Sumber: Data diolah, 2017

Keterangan :

* menunjukkan lag order yang dipilih sesuai kriteria

LR: sequential modified LR test statistic (each test at 5\% level)

FPE: Final prediction error

AIC: Akaike information criterion

SC: Schwarz information criterion

HQ: Hannan-Quinn information criterion

Sedangkan pada Tabel 4. (sesudah Brexit periode 24 Juni 2016- 31 Desember 2016) menunjukan hasil lag optimum pada uji lag length criteria dengan nilai AIC yang paling rendah ditunjukan pada lag ke-1 dengan nilai AIC sebesar 56,09090. Kemudian nilai lag optimum tersebut dapat digunakan untuk langkah selanjutnya dalam uji VAR dan uji kausalitas Granger.

Tabel 4. Hasil Uji Lag Length Criteria periode 24 Juni 2016- 31 Desember 2016

\begin{tabular}{cccllll}
\hline Lag & LogL & LR & FPE & AIC & SC & HQ \\
\hline 0 & -3671.169 & NA & $4.70 \mathrm{e}+19$ & 62.32490 & 62.46578 & 62.38210 \\
1 & -3267.363 & 759.7030 & $9.24 \mathrm{e}+16^{*}$ & $56.09090^{*}$ & $57.07708^{*}$ & $56.49132^{*}$ \\
2 & -3241.970 & 45.19182 & $1.11 \mathrm{e}+17$ & 56.27067 & 58.10214 & 57.01430 \\
3 & -3206.763 & 59.07585 & $1.14 \mathrm{e}+17$ & 56.28411 & 58.96088 & 57.37096 \\
4 & -3170.617 & 56.97609 & $1.16 \mathrm{e}+17$ & 56.28164 & 59.80369 & 57.71170 \\
5 & -3132.417 & $56.32798^{*}$ & $1.16 \mathrm{e}+17$ & 56.24436 & 60.61171 & 58.01763 \\
6 & -3106.952 & 34.96081 & $1.47 \mathrm{e}+17$ & 56.42291 & 61.63556 & 58.53940 \\
7 & -3074.599 & 41.12686 & $1.69 \mathrm{e}+17$ & 56.48473 & 62.54266 & 58.94443 \\
8 & -3045.288 & 34.27843 & $2.11 \mathrm{e}+17$ & 56.59811 & 63.50134 & 59.40102 \\
\hline
\end{tabular}

Sumber: Data diolah, 2017

Keterangan :

* menunjukkan lag order yang dipilih sesuai kriteria

LR: sequential modified LR test statistic (each test at 5\% level)

FPE: Final prediction error

AIC: Akaike information criterion

SC: Schwarz information criterion

HQ: Hannan-Quinn information criterion

Hasil analisis integrasi pasar modal dapat dilihat pada Tabel 5. yang merupakan hasil uji VAR sebelum Brexit (Januari 2012 - 22 Juni 2016), hasil ini menunjukan integrasi pasar modal dengan adanya keterkaitan pasar modal Inggris (FTSE) yang secara signifikan dipengaruhi oleh pasar modal Singapura
(STI). Sedangkan integrasi pasar modal Indonesia (IHSG) secara signifikan dipengaruhi oleh pasar modal Inggris (FTSE) dan Thailand (SETi). Kemudian integrasi pasar modal Thailand (SETi) secara signifikan dipengaruhi oleh pasar modal Inggris (FTSE), Malaysia (KLCi), dan Philipina 
Tabel 5. Hasil Uji VAR periode Januari 2012 - 22 Juni 2016

\begin{tabular}{cccccccc}
\hline Variabel & FTSE & IHSG & KLCi & PSEi & SETi & STI & Adjusted R $^{2}$ \\
\hline FTSE & & 0.065303 & -0.004570 & -0.045844 & -0.014053 & -0.001531 & 0.043272 \\
& & {$[2.59875]^{* * *}$} & {$[-0.87358]$} & {$[-1.21517]$} & {$[-1.90814]^{*}$} & {$[-0.12838]$} & \\
IHSG & 0.029047 & & 0.008686 & 0.058730 & 0.014091 & -0.002459 & 0.063352 \\
& {$[0.78469]$} & & {$[1.37602]$} & {$[1.29017]$} & {$[1.58560]$} & {$[-0.17088]$} & \\
KLCi & -0.212789 & 0.041376 & & -0.001604 & -0.080174 & -0.017392 & 0.049471 \\
& {$[-1.17314]$} & {$[0.27849]$} & & {$[-0.00719]$} & {$[-1.84120]^{*}$} & {$[-0.24665]$} & \\
PSEi & -0.021644 & 0.010756 & -0.003076 & & 0.024550 & -0.007541 & 0.050099 \\
& {$[-0.85603]$} & {$[0.51935]$} & {$[-0.71345]$} & & {$[4.04469]^{* * *}$} & {$[-0.76722]$} & \\
SETi & 0.179569 & 0.362342 & -0.021535 & 0.018460 & & 0.010946 & 0.029580 \\
& {$[1.37828]$} & {$[3.39538]^{* * *}$} & {$[-0.96926]$} & {$[0.11522]$} & & {$[0.21611]$} & \\
STI & 0.153020 & -0.019310 & -0.003072 & -0.090820 & 0.028143 & & 0.053928 \\
& {$[1.91939]^{*}$} & {$[-0.29571]$} & {$[-0.22599]$} & {$[-0.92638]$} & {$[1.47047]$} & & \\
\hline
\end{tabular}

Sumber: Data diolah, 2017

Keterangan :

Angka dalam kurung adalah nilai t-statistik

* signifikan pada tingkat $10 \%$

** signifikan pada tingkat $5 \%$

*** signifikan pada tingkat $1 \%$

(PSEi). Selanjutnya pasar modal Malaysia (KLCi), Philipina (PSEi) dan Singapura (STI) tidak memiliki integrasi dengan pasar modal lainnya atau masih tersegmentasi. Hal ini mendukung penelitian Kenani, Purnomo, and Maoni (2013); Suryanta (2011).

Tabel 6. Hasil Uji VAR periode 24 Juni 2016- 31 Desember 2016

\begin{tabular}{|c|c|c|c|c|c|c|c|}
\hline Variabel & FTSE & IHSG & KLCi & PSEi & SETi & STI & Adjusted $\mathrm{R}^{2}$ \\
\hline FTSE & & $\begin{array}{c}0.079866 \\
{[1.94409]^{*}}\end{array}$ & $\begin{array}{c}-0.013549 \\
{[-2.27489]^{* *}}\end{array}$ & $\begin{array}{l}-0.076819 \\
{[-1.21658]}\end{array}$ & $\begin{array}{c}-0.026308 \\
{[-2.34853]^{* *}}\end{array}$ & $\begin{array}{c}-0.035210 \\
{[-2.28722]^{* *}}\end{array}$ & 0.893951 \\
\hline IHSG & $\begin{array}{l}-0.010547 \\
{[-0.20030]}\end{array}$ & & $\begin{array}{c}0.011195 \\
{[1.51399]}\end{array}$ & $\begin{array}{r}0.046984 \\
{[0.59936]}\end{array}$ & $\begin{array}{c}0.022535 \\
{[1.62041]}\end{array}$ & $\begin{array}{r}0.000178 \\
{[0.00929]}\end{array}$ & 0.863661 \\
\hline KLCi & $\begin{array}{r}0.784918 \\
{[1.14777]}\end{array}$ & $\begin{array}{r}0.183246 \\
{[0.27665]}\end{array}$ & & $\begin{array}{c}4.092077 \\
{[4.01935]^{* * *}}\end{array}$ & $\begin{array}{r}0.181006 \\
{[1.00216]}\end{array}$ & $\begin{array}{c}0.415227 \\
{[1.67290]^{*}}\end{array}$ & -0.002491 \\
\hline PSEi & $\begin{array}{c}-0.005872 \\
{[-0.43260]}\end{array}$ & $\begin{array}{c}0.033074 \\
{[2.51544]^{* *}}\end{array}$ & $\begin{array}{l}-0.001926 \\
{[-1.01057]}\end{array}$ & & $\begin{array}{l}-0.005837 \\
{[-1.62797]}\end{array}$ & $\begin{array}{l}-0.004535 \\
{[-0.92036]}\end{array}$ & 0.972846 \\
\hline SETi & $\begin{array}{c}-0.142289 \\
{[-0.40833]}\end{array}$ & $\begin{array}{c}0.179918 \\
{[0.53306]}\end{array}$ & $\begin{array}{l}-0.018861 \\
{[-0.38545]}\end{array}$ & $\begin{array}{r}0.749666 \\
{[1.44507]}\end{array}$ & & $\begin{array}{r}0.063736 \\
{[0.50394]}\end{array}$ & 0.026980 \\
\hline STI & $\begin{array}{r}0.370064 \\
{[1.43227]}\end{array}$ & $\begin{array}{c}-0.459388 \\
{[-1.83565]^{*}}\end{array}$ & $\begin{array}{l}-0.024806 \\
{[-0.68370]}\end{array}$ & $\begin{array}{l}-0.390450 \\
{[-1.01506]}\end{array}$ & $\begin{array}{l}-0.081023 \\
{[-1.18732]}\end{array}$ & & 0.087313 \\
\hline
\end{tabular}

Sumber: Data diolah, 2017

Keterangan :

Angka dalam kurung adalah nilai t-statistik

*signifikan pada tingkat $10 \%$ dengan nilai T-tabel 1,65776

**signifikan pada tingkat 5\% dengan nilai T-tabel 1,98010

***signifikan pada tingkat $1 \%$ dengan nilai T-tabel 2,61778 
Pada Tabel 6 merupakan hasil uji VAR sesudah Brexit (24 Juni 2016-31 Desember 2016) menunjukan adanya integrasi pasar modal Indonesia (IHSG) secara signifikan dipengaruhi oleh pasar modal Inggris (FTSE), Philipina (PSEi) dan Singapura (STI). Sedangkan integrasi pasar modal Malaysia (KLCi) secara signifikan dipengaruhi oleh pasar modal Inggris (FTSE). Selanjutnya integrasi pasar modal Philipina (PSEi) secara signifikan dipengaruhi oleh pasar modal Malaysia (KLCi). Setelah itu integrasi Thailand (SETi) secara signifikan dipengaruhi oleh pasar modal Inggris (FTSE). Sedangkan integrasi pasar modal Singapura (STI) secara signifikan dipengaruhi oleh pasar modal Inggris (FTSE), dan Malaysia (KLCi). Akan tetapi setelah terjadinya Brexit pasar modal Inggris (FTSE) tidak terintegrasi dengan pasar modal ASEAN atau menjadi tersegmentasi. Dengan adanya guncangan peristiwa Brexit terlihat bahwa pasar modal Malaysia, dan Singapura yang sebelumnya tersegmentasi kemudian menjadi terintegrasi dengan pasar modal Inggris yang berarti keterkaitan bersifat satu arah sehingga ke empat negara Indonesia, Malaysia, Singapura, dan Thailand semakin terintegrasi dengan pasar modal Inggris. Temuan ini mendukung hasil penelitian Tai (2007); Volz (2013)

Hasil uji kausalitas granger disajikan pada Tabel 7. sebelum brexit (periode Januari 2012- 22 Juni 2016) yang menunjukkan adanya contagion effect antar pasar modal IHSG, KLCi, PSEi, SETi, STI dan FTSE. Hal ini ditunjukan dengan adanya FTSE yang memiliki Contagion effect terhadap KLCi dan STI, sebaliknya STI juga memiliki contagion effect ke FTSE, sedangkan KLCi tidak memiliki contagion effect ke FTSE, serta FTSE tidak memiliki contagion effect ke IHSG, PSEi, dan SETi. Kemudian IHSG memiliki Contagion effect terhadap KLCi, tetapi KLCi tidak memiliki contagion effect ke IHSG, serta IHSG tidak memiliki contagion effect ke FTSE dan STI. Selanjutnya KLCi memiliki contagion effect ke STI, begitupula sebaliknya STI juga memiliki contagion effect ke KLCi. Ditemukan lebih lanjut PSEI memiliki contagion effect ke IHSG, KLCi, SETi, sebaliknya SETi juga memiliki contagion effect ke PSEi, sedangkan IHSG dan KLCi tidak memiliki contagion effect ke PSEi, serta PSEi juga tidak memiliki contagion effect ke FTSE dan STI. Setelah itu SETi memiliki contagion effect ke IHSG dan KLCi, sedangkan IHSG dan KLCi tidak memiliki contagion effect ke SETi, kemudian SETi tidak memiliki contagion effect ke FTSE dan STI, begitu pula STI juga tidak memiliki contagion effect ke
IHSG, PSEi dan SETi. Contagion effect yang terjadi sangat terlihat bahwa pasar modal dinegara yang lebih maju akan mempengaruhi pasar modal yang masih berkembang, seperti halnya pasar modal Inggris mempengaruhi pasar modal Singapura dan Malaysia, begitupula pasar modal Singapura juga memiliki pengaruh ke pasar modal Inggris sehingga terjadi pengaruh dua arah antara kedua pasar modal. Sebelum Brexit pasar modal Malaysia paling banyak terkena efek penularan dari pasar modal Inggris, Indonesia, Philpina, Thailand dan Singapura, kemudian disusul dengan pasar modal Indonesia yang mendapat efek penularan dari dua pasar modal yaitu Philpina dan Thailand hal ini dapat disebabkan adanya perbedaan waktu jam perdagangan bursa antar negara sebagaimana juga ditemukan oleh Craig, Dravid, and Richardson (1995).

Pembahasan selanjutnya pada Tabel 7. sesudah Brexit (24 Juni 2016- 31 Desember 2016) menunjukan bahwa adanya perubahan antara keterkaitan pasar modal antara IHSG, KLCi, PSEi, SETi, STI dan FTSE sesudah terjadi peristiwa Brexit. Hal ini dapat dilihat pada FTSE yang memiliki contagion effect ke PSEI dan STI, sebaliknya STI juga memiliki contagion effect ke FTSE, sedangkan PSEi tidak memiliki contagion effect ke FTSE, serta FTSE tidak memiliki contagion effect ke IHSG, KLCi, dan SETi. Kemudian IHSG memiliki contagion effect terhadap STI, begitupula sebaliknya STI juga memiliki contagion effect terhadap IHSG, serta IHSG tidak memiliki contagion effect ke FTSE, KLCi, PSEi, dan SETi. Selanjutnya KLCi memiliki contagion effect terhadap PSEi, sedangkan PSEi tidak memiliki contagion effect terhadap KLCi, serta KLCi tidak memiliki contagion effect ke FTSE, IHSG, SETi, dan STI. Lebih lanjut ditemukan bahwa bahwa SETi memiliki contagion effect ke PSEi, sedangkan PSEI tidak memiliki contagion effect ke SETi, serta PSEi juga tidak memiliki contagion effect ke IHSG, SETi, dan STI. Sedangkan SETi tidak memiliki contagion effect ke FTSE, IHSG, KLCi, dan STI, begitupula dengan STI juga tidak memiliki contagion effect terhadap KLCi, PSEi, dan SETi. Sesudah Brexit pasar modal Singapura masih mendapat efek penularan dari pasar modal Inggris secara dua arah. Kemudian sesudah Brexit efek penularan pada pasar modal Malaysia menjadi lenyap, hanya medapat efek penularan dari Philipina, akan tetapi sesudah Brexit pasar modal Philipina tidak menerima efek penularan dari pasar modal Inggris, Indonesia, Malaysia, Thailand, dan Singapura. 
Tabel 7. Hasil Uji Kausalitas Granger

\begin{tabular}{|c|c|c|c|c|c|c|}
\hline \multirow[t]{2}{*}{ Null Hypothesis: } & \multicolumn{3}{|c|}{ Januari 2012 - 22 Juni 2016} & \multicolumn{3}{|c|}{24 Juni 2016- 31 Desember 2016} \\
\hline & Obs & F-Statistic & Prob. & Obs & F-Statistic & Prob. \\
\hline IHSG does not Granger Cause FTSE & 1103 & 0,56605 & 0,7261 & 126 & 0,01799 & 0,8935 \\
\hline FTSE does not Granger Cause IHSG & & 1,57338 & 0,1647 & & 0,74106 & 0,391 \\
\hline KLCi does not Granger Cause FTSE & 1113 & 0,50904 & 0,7696 & 126 & 2,5054 & 0,116 \\
\hline FTSE does not Granger Cause KLCi & & 2,37797 & $0,037 * *$ & & 2,39472 & 0,1243 \\
\hline PSEi does not Granger Cause FTSE & 1081 & 0,5067 & 0,7714 & 127 & 0,12608 & 0,7231 \\
\hline FTSE does not Granger Cause PSEi & & 1,40269 & 0,2206 & & 2,84329 & $0,0943 *$ \\
\hline SETi does not Granger Cause FTSE & 1087 & 1,65495 & 0,1428 & 127 & 0,10422 & 0,7474 \\
\hline FTSE does not Granger Cause SETi & & 0,6877 & 0,6328 & & 1,32142 & 0,2525 \\
\hline STI does not Granger Cause FTSE & 1116 & 9,22776 & $1,00 \mathrm{E}-08^{* * *}$ & 130 & 4,2429 & $0,0415^{* *}$ \\
\hline FTSE does not Granger Cause STI & & 3,0382 & $0,0099 * * *$ & & 10,6311 & $0,0014 * * *$ \\
\hline KLCi does not Granger Cause IHSG & 1103 & 1,52966 & 0,1777 & 125 & 0,13312 & 0,7158 \\
\hline IHSG does not Granger Cause KLCi & & 4,40225 & $0,0006^{* * *}$ & & 0,00284 & 0,9576 \\
\hline PSEi does not Granger Cause IHSG & 1081 & 5,80816 & $3,00 \mathrm{E}-05^{* * *}$ & 126 & 1,78567 & 0,1839 \\
\hline IHSG does not Granger Cause PSEi & & 0,85648 & 0,5099 & & 0,23983 & 0,6252 \\
\hline SETi does not Granger Cause IHSG & 1087 & 9,41657 & $8,00 \mathrm{E}-09^{* * *}$ & 125 & 0,10345 & 0,7483 \\
\hline IHSG does not Granger Cause SETi & & 1,30774 & 0,2582 & & 0,00439 & 0,9473 \\
\hline STI does not Granger Cause IHSG & 1103 & 0,50734 & 0,7709 & 125 & 3,65884 & $0,0581^{*}$ \\
\hline IHSG does not Granger Cause STI & & 1,78399 & 0,1133 & & 4,65941 & $0,0328 * *$ \\
\hline PSEi does not Granger Cause KLCi & 1081 & 2,59152 & $0,0244 * *$ & 126 & 0,14319 & 0,7058 \\
\hline KLCi does not Granger Cause PSEi & & 0,76266 & 0,5768 & & 17,756 & $5,00 \mathrm{E}-05^{* * *}$ \\
\hline SETi does not Granger Cause KLCi & 1087 & 3,20128 & $0,0071 * * *$ & 126 & 0,04047 & 0,8409 \\
\hline KLCi does not Granger Cause SETi & & 1,46599 & 0,1982 & & 0,89818 & 0,3451 \\
\hline STI does not Granger Cause KLCi & 1113 & 3,02793 & $0,0101 * * *$ & 126 & 0,30006 & 0,5848 \\
\hline KLCi does not Granger Cause STI & & 8,35148 & $9,00 \mathrm{E}-08 * * *$ & & 2,55497 & 0,1125 \\
\hline SETi does not Granger Cause PSEi & 1081 & 8,06462 & $2,00 \mathrm{E}-07 * * *$ & 126 & 5,04551 & $0,0265^{* *}$ \\
\hline PSEi does not Granger Cause SETi & & 6,41363 & $7,00 \mathrm{E}-06 * * *$ & & 0,10975 & 0,741 \\
\hline STI does not Granger Cause PSEi & 1081 & 1,17279 & 0,3205 & 126 & 0,0429 & 0,8363 \\
\hline PSEi does not Granger Cause STI & & 0,34926 & 0,8829 & & 0,00027 & 0,9868 \\
\hline STI does not Granger Cause SETi & 1087 & 1,7319 & 0,1245 & 127 & 0,60675 & 0,4375 \\
\hline SETi does not Granger Cause STI & & 1,48719 & 0,1912 & & 2,05977 & 0,1538 \\
\hline
\end{tabular}

Sumber: Data diolah, 2017

Keterangan :

*signifikan pada tingkat $10 \%$

**signifikan pada tingkat $5 \%$

****signifikan pada tingkat $1 \%$

\section{SIMPULAN}

Adanya peristiwa Brexit dapat mengubah kawasan ASEAN-5 yang tersegmentasi menjadi lebih terintegrasi. Penelitian ini memberikan bukti adanya integrasi pasar modal dan contagion effect pada pasar modal Indonesia (IHSG), Malaysia (KLCi), Philipina (PSEi), Thailand (SETi), Singapura
(STI) dan Inggris (FTSE) baik sebelum dan sesudah peristiwa Brexit. Hal ini ditunjukan dengan adanya hasil uji VAR dan uji kausalitas Granger yang menunjukan bahwa sebelum Brexit dan sesudah Brexit ditemukan adanya beberapa integrasi pasar modal yang terjadi antar pasar modal antara IHSG, KLCi, PSEi, SETi, STI dan FTSE, akan tetapi 
integrasi antar pasar modal yang terbentuk tidak bersifat keseluruhan, baik integrasi dalam kawasan ASEAN maupun integrasi dengan pasar modal Inggris. Ada tiga pasar modal yang masih tersegmentasi sebelum Brexit yaitu pasar modal Malaysia, Philpina dan Singapura, akan tetapi setelah adanya guncangan peristiwa Brexit ketiga pasar modal tersebut menjadi saling terintegrasi. Kemudian hasil uji Kausalitas Granger menunjukan bahwa sebelum dan sesudah Brexit terdapat beberapa contagion effect antar pasar modal IHSG, KLCi, PSEi, SETi, STI dan FTSE, yang mana pasar modal Singapura paling terkena efek penularan dari pasar modal Inggris baik sebelum dan sesudah Brexit. Akan tetapi pasar modal Indonesia, Malaysia, Philipina, dan Thailand hanya mendapat efek antar kawasan ASEAN baik sebelum dan sesudah Brexit, dan tidak terkena langsung dari pasar modal Inggris. Kemudian pasar modal Malaysia paling banyak mendapat efek penularan dari pasar modal Inggris, Indonesia, Philpina, Thailand dan Singapura sebelum Brexit terjadi, tetapi setelah Brexit efek penularan tersebut lenyap tinggal efek penularan dari pasar modal Philipina. Berbeda dengan Philipina sesudah terjadi peristiwa Brexit tidak menerima contagion effect sama sekali dari semua negara.

Dalam pembentukan portofolio internasional khususnya di bidang investasi pasar modal tentu tidak dapat dipungkiri dari adanya pengaruh peristiwa global yang dapat mempengaruhi pergerakan pasar modal beberapa negara dikawasan ASEAN, hal ini ditunjukan dengan adanya bukti bahwa keterkaitan pasar modal antar negara baik kawasan dan global masih terdapat keterkaitan sehingga investor perlu memperhatikan adanya peristiwa-peristiwa global yang terjadi dan harus memiliki ketrampilan menganalisis lebih mendalam kemungkinan-kemungkinan dampak yang akan muncul serta pengaruh terhadap pasar modal di Indonesia khususnya, sehingga disarankan kepada investor agar dalam pembentukan portofolio investasinya lebih baik menggunakan pasar modal pada satu negara dibandingkan beberapa negara, dikarenakan semakin terintegrasi antar pasar modal maka risiko investasi semakin besar, hal ini bisa dilihat dari adanya keterkaitan yang bersifat positif jadi ketika satu pasar modal mengalami guncangan maka akan mempengaruhi pasar modal lainnya. $I$

Penelitian ini mendukung pengembangan teori portofolio modern, teori International Capital Asset Pricing Model dan teori integrasi pasar modal.
Penelitian ini membuktikan bahwa pasar modal pada satu kawasan akan cenderung terintegrasi sehingga portofolio internasional tidak besar manfaatnya. Pengembangan kajian teori integrasi pasar modal dan contagion effect masih dapat dijadikan kajian yang menarik terlebih dengan adanya kesepakatan antar negara anggota kawasan ASEAN yang telah melakukan cetak biru ASEAN Economic Community (AEC), yang akan membuat tingkat pertumbuhan ekonomi antar negara anggota semakin meningkat sehingga perlu dikaji lebih lanjut realisasi dari kesepakatan AEC tersebut.

Penelitian ini menggunakan periode jangka pendek kurang dari satu tahun untuk periode sesudah terjadi peristiwa Brexit serta pengesahan peraturan keluarnya Inggris dari Anggota Uni Eropa masih dalam proses pengurusan sehingga belum memiliki dampak yang terlalu signifikan akan tetapi terlihat bahwa Brexit memberikan efek kejut terhadap pasar modal beberapa negara di kawasan ASEAN. Di samping itu selama periode penelitian ada beberapa peristiwa lain yang dapat mempengaruhi ketidakpastian ekonomi global seperti adanya perlambatan ekonomi Tiongkok awal tahun 2016 dan terpilihnya Donald Trump sebagai Presiden Amerika Serikat pada 8 November 2016. Oleh sebab itu penelitian mendatang perlu secara khusus melakukan kajian pada peristiwa-peristiwa tersebut dan menghindarkan adanya confounding effect.

\section{REFERENSI}

Arsyad, N. (2015). Integration Between East and Southeast Asian Equity Markets. Journal of Financial Economic Policy, 17(2), 104-121. doi: 10.1108/JFEP-02-2014-0012

Craig, A., Dravid, A., dan Richardson, M. (1995). Market Efficiency Around the Clock: Some Supporting Evidence Using Foreign Based Derivatives. Journal of Financial Economics, 39, 161-180. doi: https://doi.org/ 10.1016/0304-405X(94)00822-I

Daly, T. P. T. K. (2012). The Impacts of the Global Financial Crisis on Southeast Asian Equity Markets Integration. International Journal of Trade, Economics and Finance, 3(4), 299304.

DBS. (2017). DBS Insights Retrieved February 20, 2018, from www.dbsinsights.com

FKMHII. (2016). Regionalisme: Fenomena "Brexit" Dampak bagi Inggris, Uni Eropa dan Dunia 
Retrieved February 21, 2018, from http:// fkmhii.com/2016/11/12/regionalisme-fenomenabrexit-dampak-bagi-inggris-uni-eropa-dan-dunia/

G. Papavassiliou, V. (2014). Equity market integration: the new emerging economy of Montenegro. Review of Accounting and Finance, 13(3), 291-306. doi: 10.1108/raf-052013-0073

Ibrahim, M. H. (2006). International Linkage of ASEAN Stock Prices: An Analysis of Response Asymmetries. Applied Econometrics and International Development, 3(3), 191-202.

Karim, B. A., dan Karim, Z. A. (2012). Integration of ASEAN-5 Stock Markets: A Revisit. Asian Academy of Management Journal of Accounting and Finance, 8(2), 21-41.

Kenani, J. M., Purnomo, J., dan Maoni, F. (2013). The Impact of the Global Financial Crisis on the Integration of the Chinese and Indonesian Stock Markets. International Journal of Economics and Finance, 5(9), 69-81.

Liaw, K. T. (2004). Capital Market. Mason, Ohio: Thomson/South Western.

Mensi, W., Beljid, M., Boubaker, A., dan Managi, S. (2013). Correlations and Volatility Spillovers Across Commodity and Stock Markets: Linking Energies, Food, and Gold. Economic Modelling, 32, 15-22. doi: 10.1016/ j.econmod.2013.01.023

Muharam, H. (1999). Dampak Pelepasan Batas Kepemilikan Asing Terhadap Terintegrasinya Bursa Efek Jakarta dengan Bursa Efek Internasional (Studi Literatur). Jurnal Bisnis Strategi, 4.

Mulyadi, M. S. (2012). Analysis of Volatility Spillover in Indonesia, USA and Japan Capital Market. African Journal of Business Management, 6(27). doi: 10.5897/ajbm11.2054

Nainggolan, P. P. (2016). "Brexit": Penyebab dan Implikasi Globalnya Majalah Info Singkat: Kajian Singkat Terhadap Isu Aktual dan Strategis, 8(12).

Robiyanto, R. (2017a). The Analysis of Capital Market Integration in ASEAN Region by Using the OGARCH Approach. Jurnal Keuangan dan Perbankan 21(2), 169-175.

Robiyanto, R. (2017b). Performance evaluation and risk aversion rate for several stock indices in Indonesia Stock Exchange. Jurnal Manajemen dan Kewirausahaan, 19(1), 6064. doi: 10.9744/jmk.19.1.60-64
Robiyanto, R. (2018a). The dynamic correlation between ASEAN-5 stock markets and world oil prices. Jurnal Keuangan dan Perbankan, 22(2), 198-210. doi: https://doi.org/10.26905/ jkdp.v22i2.1688

Robiyanto, R. (2018b). Indonesian Stock Market's Dynamic Integration with Asian Stock Markets and World Stock Markets. Jurnal Pengurusan, 52, 181-192. doi: 10.17576/pengurusan-201852-15

Robiyanto, R., dan Ernayani, R. (2018). Capital market integration in some ASEAN countries revisited. Jurnal Manajemen, 22(2), 205-222. doi: http://dx.doi.org/10.24912/jm.v22i2.359

Robiyanto, R., dan Hartanto, A. F. (2018). Contagion effect dan integrasi pasar modal di kawasan Asia, Eropa dan Amerika. Jurnal Organisasi Dan Manajemen, 14(1), 1-10.

Robiyanto, R., Hersugondo, H., dan Chotijah, G. S. (2016). ASEAN Economic Community (AEC) and Economic Stability: A Review from Indonesia's Side. International Journal of Economic Research, 13(2).

Robiyanto, R., Wahyudi, S., dan Pangestuti, I. R. D. (2017a). Testing Commodities as Safe Haven and Hedging Instrument on ASEAN's Five Stock Markets Jurnal Ekonomi Kuantitatif Terapan, 10(2), 231-238. doi: 10.24843/JEKT.2017.v10.i02.p11

Robiyanto, R., Wahyudi, S., dan Pangestuti, I. R. D. (2017b). The volatility-variability hypotheses testing and hedging effectiveness of precious metals for the Indonesian and Malaysian capital markets. Gadjah Mada International Journal of Business, 19(2), 167-192. doi: 10.22146/ gamaijb.26260

Seth, N., dan Sharma, A. K. (2015). International Stock Market Efficiency and Integration: Evidences from Asian and US Markets. Journal of Advances in Management Research, 12(2), 88-106. doi: 10.1108/JAMR07-2011-0010

Soesastro, H. (2004). Kebijakan Persaingan, Daya Saing, Liberalisasi, Globalisasi, Regionalisme dan Semua Itu Economics Working Paper Series CSIS

Suganda, T. R., dan Soetrisno, Y. (2016). Uji Integrasi dan Contagion Effect Pasar Modal Pada Lima Negara ASEAN (Riset Empiris Pasca Terjadinya Krisis Subprime Mortgage dan 
86 Matrik: Jurnal Manajemen, Strategi Bisnis dan Kewirausahaan Vol. 13, No. 1, Februari 2019

Krisis Yunani). Jurnal Keuangan dan Perbankan 20(2), 252-262.

Suryanta, B. (2011). Capital Market Integration in ASEAN Countries: Special Investigation of Indonesian Towards the Big Four. Asian Journal of Technology Management, 4(2), 109-114.

Tai, C.-S. (2007). Market Integration and Contagion: Evidence from Asian Emerging Stock and Foreign Exchange Markets. Emerging Markets Review, 8(4), 264-283
Valle, R. S. (1999). A Cointegration Analysis of Latin America Stock Markets and the U.S. SSRN Working Paper.

Volz, U. (2013). ASEAN Financial Integration in the Light of Recent European Experiences. Journal of Southeast Asian Economics, 30(2), 124-142.

Widarjono, A. (2016). Ekonometrika: Pengantar dan Aplikasinya. Yogyakarta: UPP STIM YKPN. 